\title{
Meeting Dividend Thresholds through Earnings Management: A Cross-cultural Comparison
}

\author{
Yi-Shu Wang ${ }^{1}$, Jing Yang ${ }^{2}$, Zhen-Jia Liu ${ }^{3}$ \\ ${ }^{1}$ School of Business, Changzhou University, Changzhou City, Jiangsu Providence, China \\ Correspondence: Zhen-Jia Liu, School of Business, Changzhou University, Changzhou City, Jiangsu, China.
}

Received: October 6, 2016

Accepted: February 20, 2017

Available online: February 22, 2017

doi:10.11114/aef.v4i3.1908

URL: https://doi.org/10.11114/aef.v4i3.1908

\begin{abstract}
Culture affects accounting rules and practices. Dividend distribution influences corporate operating decisions, and a previous year's dividends represent an earnings threshold. This study collected various countries' data from 2004 to 2014 from the COMPUSTAT database and analyzed how cultural factors influence the management of income to achieve a dividend threshold (i.e., desired earnings goal). Prospect theory reported that managers making decisions focus on the value from gains or losses with a certain reference point rather than the levels of wealth. The empirical results show that managers of listed firms in societies that exhibit uncertainty-avoidance, individualistic, power-distance, and masculinity meet or exceed dividend thresholds, whereas those in long term orientation societies do not. These findings emphasize the strong and direct effect of cultural values on meeting or exceeding dividend thresholds through earnings management over multiple years. In addition, our empirical results suggest that investors evaluate firm performance (i.e., earnings) before dividends are paid, which should be considered by financial market participants and regulators when assessing financial statements and the reliability of financial reporting among multiple countries. We only used a modified Jones model to measure earnings management. Therefore, tradeoff tools (i.e., real activities or other DA models) should be used to examine earnings management among managers to ensure the robustness of future studies.
\end{abstract}

Keywords: dividend thresholds, earnings management, culture

\section{Introduction}

Earnings management is subjective, because managers can adjust financial reports and structure transactions to mislead stakeholders regarding the (Healy and Wahlen, 1999). Empirical results have suggested that to satisfy stakeholders, firms conduct evaluations to determine whether earnings thresholds, such as change in earnings above zero (Heidarpoor et al., 2014), positive earnings (Sun and Rath, 2012), and analyst forecasts (Athanasakou et al.2011), as well as dividend thresholds are met (Daniel et al.2008; Liu and Espahbodi, 2014; Dechow et al. 2010b; Koren and Valentincic, 2013). Managers appear willing to expend considerable effort in avoiding dividend cuts (Lintner, 1956), because dividends are crucial to investors (Deangelo and DeAngelo, 2006a). Furthermore, the importance of pay-out policies for firms (as signaling mechanisms, for clients, and for tax-induced decisions) and firms' economic environment indicates that pay-out threshold analysis is critical (Koren and Valentincic, 2013).

The culture in which a corporation operates may influence its ethical behavior (Zhang et al. 2013) as well as its accounting rules and practices (Han et al. 2010). Previous studies have determined that earnings management among various countries were attributed to cultural factors, demonstrating that culture influences earnings management (Doupnik, 2008; Callen et al. 2011; Zhang et al. 2013; Kanagaretnam et al. 2011; Doupnik and Tsakumis, 2004). Cross-country differences in firms' propensity to pay dividends and level of dividend payments are also likely to be affected by differences in national culture that may influence excessive earnings retention or payment as dividends (Zheng and Ashraf, 2014; Bae et al.,2012; Ashraf,2014; Khambata \& Liu.2005; Shao et al., 2009; Fidrmuc \& Jacob, 2010), however, these studies have been largely ignored, regardless of whether corporations' earnings management resulted in meeting or exceeding dividend thresholds.

In this study, we used dividend thresholds to measure earnings thresholds. Furthermore, we used power distance, individualism, uncertainty avoidance, masculinity, and long-term orientation to measure cultural dimensions. The purpose of this study was to clarify perceptions regarding the manipulation of income toward a desired earnings goal 
(i.e., dividend threshold) and whether those perceptions are influenced by cultural factors.

\section{Literature Review}

\subsection{Earnings Management}

Francoeur et al. (2012) manipulated earnings through discretionary accruals (DAs) in he previous and current year involving merger and acquisition activities. Zhang and He (2013) determined that firms engage in earnings management through research and development expenditures. Chiu et al. (2013) reported that shared directors have more incentive to manage earnings when their position is related to accounting or leadership. Farrell et al. (2014) determined that firms that incur financing constraints are likely to engage in earnings management by using accrual-based and real activities. Degeorge et al. (2013) reported that in highly financially developed countries, firms with analyst coverage engage in less earnings management because this coverage mitigates monitoring costs. Karampinis and Hevas (2013) revealed that tax is significantly related to earnings management during the period before the adoption of the International Financial Reporting Standards.

\subsection{Earnings Thresholds}

Sun and Rath (2012) demonstrated that firms are likely to avoid negative earnings through earnings management by using DAs. Moreover, Heidarpoor et al. (2014) revealed that firms manage earnings to maintain a positive earnings change, and Athanasakou et al. (2011) indicated that firms manage earnings to achieve analyst thresholds.

\subsection{Culture and Dividend Thresholds}

Maintaining dividend thresholds is a critical role for managers; therefore, they tend to manage earnings to achieve this goal (Liu and Espahbodi, 2014; Dechow et al. 2010b; Koren and Valentincic, 2013 ; Bennet and Bradbury, 2007; Peterson and Whitworth, 2013). Uncertainty avoidance implies a preference for non-ambiguity, and it thus results in earnings management (Callen et al. 2011; Zhang et al. 2013; Guan and Pourjalali, 2010), which reduces the level of uncertainty (Callen et al. 2011; Zhang et al. 2013). Doupnik and Tsakumis (2004) also determined that earnings may be managed because managers intend to prevent unfavorable and unanticipated earnings, particularly in uncertainty-avoidance societies. Therefore, managers in such societies are likely to achieve dividend thresholds. We propose the following hypothesis:

H1: Firms in higher uncertainty-avoidance societies are likely to achieve dividend benchmarks by manipulating earnings.

Hofstede $(1980,2001)$ demonstrated that people in individualistic societies are often considered to be respectful and protect everyone's rights, and they thus assert laws, rules, or regulations that protect people or their rights. Consequently, people in individualistic societies tend to comply with laws or rules. Therefore, individualistic societies exhibit a significantly negative relationship with earnings management (Desender et al. 2011; Callen et al. 2011; Zhang et al. 2013), because law enforcement is generally strong (Zhang et al. 2013), and accounting rules are stringent, particularly high-level regulatory monitoring, which impedes financial misreporting (Nabar and Boonlert-U-Thai, 2007). Because managers in individualistic societies may not manage earnings, corporations in such societies are not likely to consider exceeding earnings thresholds (i.e., dividend thresholds) a major goal. We propose the following hypothesis:

H2: firms are not likely to meet/beat dividend thresholds through earnings management in higher individualistic societies.

Power distance describes the level of power (i.e., equality or inequality) between people who interact with one another. Hofstede and Hofstede (2005) asserted that accounting systems are a tool that can be used by a power holder to demonstrate a desired image. Accounting numbers are thus distorted to achieve desired images in these societies. Guan and Pourjalali (2010) as well as Kinnunen and Koskela (2003) demonstrated that societies characterized by high power-distance exhibit a significantly positive relationship with earnings management, because individuals accept human authority and inequality (Kinnunen and Koskela, 2003) and do not demand power equalization or justification for power inequalities (Guan and Pourjalali, 2010). Therefore, managers in high-power-distance societies are likely to manage earnings because outsiders accept power inequalities, and consequently, accounting numbers can be distorted, enabling managers to meet or exceed earnings thresholds (i.e., dividend thresholds). We propose the following hypothesis:

H3: firms are likely to meet/beat dividend thresholds through earnings management in higher power-distance societies.

Masculinity refers to the extent to which a country emphasizes traditional male characters such as male achievement, control, and power. Hofstede (1980) suggested that people in high-masculinity societies seek to obtain achievements by gaining wealth or other means. Guan and Pourjalali (2010) determined that masculinity is associated with earnings management because of its emphasis on visible achievement. Performance because of misreporting in financial statements (Nabar and Boonlert-U-Thai, 2007; Guan and Pourjalali, 2010). Consequently, managers in high-masculinity 
societies tend to frequently manage earnings, possibly enabling them to meet or exceed earnings thresholds (i.e., dividend thresholds). We propose the following hypothesis:

H4:firms are likely to meet/beat dividend thresholds through earnings management in higher masculinity societies.

Long-term orientation refers to the level at which a country devotes to traditional or forward-thinking values during a long-term period. Howevert and Hofstede (2005) showed that managers in short-term orientation societies focus on only current earnings. Current profits are often accelerated by earnings management influenced by management decisions. Therefore, earnings management is less frequently implemented in long-term-oriented societies, indicating that firms in such societies are less likely to meet or exceed earnings thresholds (i.e., dividend thresholds) compared with those in short-term-oriented societies. We propose the following hypothesis:

H5: firms are not likely to meet/beat dividend thresholds through earnings management in higher long-term-oriented societies.

\section{Methodology}

Data from 2004 to 2014 were collected from the COMPUSTAT database. We used the following variables and research model.

\subsection{Earnings Management}

Discretionary accruals (DA) are components of total accruals that are susceptible to manipulation by managers and have been used frequently as a proxy for earnings management in previous studies, where the value of $i t \quad$ was adopted to measure DAs. (Dechow et al. 1995)

$$
\frac{A C C_{i t}}{T A_{i t-1}}=\frac{\beta_{0}}{T A_{i t-1}}+\beta_{1} \frac{\Delta S A L E S_{i t}-\Delta A R_{i t}}{T A_{i t-1}}+\beta_{2} \frac{P P E_{i t}}{T A_{i t-1}}+\varepsilon_{i t}
$$

where $A C C_{i t}$ represents the total accruals calculated as the continuing operating net profit minus the cash flow

from operations for year $t ; T A_{i t-1}$ denotes the assets for year $t-1 ; \quad \Delta S A L E S_{i t}$ is the change in sales for year $t ; \quad \Delta A R_{t}$

is the change in account receivables for year $t$; and $P P E_{i t}$ is the gross fixed assets for year $t$.

\subsection{Dividend Thresholds}

Daniel et al. (2008) reported that "expected dividends" represent an earnings threshold, and a firm's expected dividend is measured as the previous year's cash dividend; pre-managed earnings can thus be expressed as the operating cash flow plus nondiscretionary total accruals minus preferred dividends. We defined dividend thresholds as being exceeded when managed earnings (pre-managed earnings plus discretionary total accruals) are higher than expected dividend payments.

\subsection{Cultural Dimensions}

We defined a country's cultural orientation according to the scale of Hofstede et al. (2010). We determined that if a country's cultural orientation score on this scale is lower than 50, then the country's culture is relatively low; otherwise, the culture is high. These measures include scores for power distance, individualism, uncertainty avoidance, masculinity, long-term orientation. Each country exhibited five cultural dimensions. We applied only the five cultural dimensions that were relevant in countries; thus, the sample size was 64 countries in this study (see Table 1) 
Table 1. Culture dimensions of nations

\begin{tabular}{|c|c|c|c|c|c|}
\hline Country & UA & IND & PD & MAS & LTO \\
\hline Argentina & 86 & 46 & 49 & 56 & 20 \\
\hline Australia & 51 & 90 & 38 & 61 & 21 \\
\hline Austria & 70 & 55 & 11 & 79 & 60 \\
\hline Bangladesh & 60 & 20 & 80 & 55 & 47 \\
\hline Belgium & 94 & 75 & 65 & 54 & 82 \\
\hline Brazil & 76 & 38 & 69 & 49 & 44 \\
\hline Bulgaria & 85 & 30 & 70 & 40 & 69 \\
\hline Canada & 48 & 80 & 39 & 52 & 36 \\
\hline Chile & 86 & 23 & 63 & 28 & 31 \\
\hline China & 30 & 20 & 80 & 66 & 87 \\
\hline Colombia & 80 & 13 & 67 & 64 & 13 \\
\hline Croatia & 80 & 33 & 73 & 40 & 58 \\
\hline Czech Rep & 74 & 58 & 57 & 57 & 70 \\
\hline Denmark & 23 & 74 & 18 & 16 & 35 \\
\hline El Salvador & 94 & 19 & 66 & 40 & 20 \\
\hline Estonia & 60 & 60 & 40 & 30 & 82 \\
\hline Finland & 59 & 63 & 33 & 26 & 38 \\
\hline France & 86 & 71 & 68 & 43 & 63 \\
\hline Germany & 65 & 67 & 35 & 66 & 83 \\
\hline Great Britain & 35 & 89 & 35 & 66 & 51 \\
\hline Greece & 112 & 35 & 60 & 57 & 45 \\
\hline Hong Kong & 29 & 25 & 68 & 57 & 61 \\
\hline Hungary & 82 & 80 & 46 & 88 & 58 \\
\hline India & 40 & 48 & 77 & 56 & 51 \\
\hline Indonesia & 48 & 14 & 78 & 46 & 62 \\
\hline Iran & 59 & 41 & 58 & 43 & 14 \\
\hline Ireland & 35 & 70 & 28 & 68 & 24 \\
\hline Israel & 81 & 54 & 13 & 47 & 38 \\
\hline Italy & 75 & 76 & 50 & 70 & 61 \\
\hline Japan & 92 & 46 & 54 & 95 & 88 \\
\hline Korea South & 85 & 18 & 60 & 39 & 100 \\
\hline Latvia & 63 & 70 & 44 & 9 & 69 \\
\hline Lithuania & 65 & 60 & 42 & 19 & 82 \\
\hline Luxembourg & 70 & 60 & 40 & 50 & 64 \\
\hline Malaysia & 36 & 26 & 104 & 50 & 41 \\
\hline Malta & 96 & 59 & 56 & 47 & 47 \\
\hline Mexico & 82 & 30 & 81 & 69 & 24 \\
\hline Morocco & 68 & 46 & 70 & 53 & 14 \\
\hline Netherlands & 53 & 80 & 38 & 14 & 67 \\
\hline New Zealand & 49 & 79 & 22 & 58 & 33 \\
\hline Norway & 50 & 69 & 31 & 8 & 35 \\
\hline Pakistan & 70 & 14 & 55 & 50 & 50 \\
\hline Peru & 87 & 16 & 64 & 42 & 25 \\
\hline Philippines & 44 & 32 & 94 & 64 & 27 \\
\hline Poland & 93 & 60 & 68 & 64 & 38 \\
\hline Portugal & 104 & 27 & 63 & 31 & 28 \\
\hline Romania & 90 & 30 & 90 & 42 & 52 \\
\hline Russia & 95 & 39 & 93 & 36 & 81 \\
\hline Serbia & 92 & 25 & 86 & 43 & 52 \\
\hline Singapore & 8 & 20 & 74 & 48 & 72 \\
\hline Slovak Rep & 51 & 52 & 104 & 110 & 77 \\
\hline Slovenia & 88 & 27 & 71 & 19 & 49 \\
\hline South Africa & 49 & 65 & 49 & 63 & 34 \\
\hline Spain & 86 & 51 & 57 & 42 & 48 \\
\hline Sweden & 29 & 71 & 31 & 5 & 53 \\
\hline Switzerland & 58 & 68 & 34 & 70 & 74 \\
\hline Taiwan & 69 & 17 & 58 & 45 & 93 \\
\hline Thailand & 64 & 20 & 64 & 34 & 32 \\
\hline Trinidad and Tobago & 55 & 16 & 47 & 58 & 13 \\
\hline Turkey & 85 & 37 & 66 & 45 & 46 \\
\hline U.S.A. & 46 & 91 & 40 & 62 & 26 \\
\hline Uruguay & 100 & 36 & 61 & 38 & 26 \\
\hline Venezuela & 76 & 12 & 81 & 73 & 16 \\
\hline Vietnam & 30 & 20 & 70 & 40 & 57 \\
\hline
\end{tabular}

UA: uncertainty-avoidance, IND :individualism, PD :power-distance, MAS :masculinity, LTO :long-term orientation 


\subsection{Model}

We examined the frequency distribution of earnings by using the approach of Burgstahler and Dichev (1997). We redefined distribution of earnings as the "managed earnings" minus the expected dividend payments scaled by the beginning-of-period market value of equity.

\subsection{Robustness Test}

The samples in this study include only data from the 1th to 99th percentiles as measures for the robustness test to minimize the impact of outliers

\section{Empirical Results}

\subsection{Descriptive Statistics}

As shown in Table 2 (modified Jones model), the $1 / T A_{i t-1}$ coefficient was significantly negative, the $\frac{\Delta S A L E S_{i t}-\triangle A R_{i t}}{T A_{i t-1}}$ coefficient was positive, and the $\frac{P P E_{i t}}{T A_{i t-1}}$ coefficient was negative. These results revealed that total accruals were increased when companies possessed more assets; moreover, the change in sales was subtracted from the change in account receivables and divided by the lagged assets. However, total accruals decreased when companies obtained more gross fixed assets. As indicated in Table 3, the mean DA values (modified Jones model) were positive in societies characterized by power distance, uncertainty avoidance, and long-term orientation. Therefore, managers in these societies who conducted earnings management through DAs were considered income-increasing, performance-adjusted discretionary items (Chen et al. 2011)

Furthermore, the magnitude values were higher for power distance and lower for uncertainty avoidance. In addition, the mean DA values (modified Jones model) were negative in societies that were characterized by individualism and masculinity. Therefore, managers in these societies who conducted earnings management through DAs were considered income-decreasing, performance-adjusted discretionary items (Chen et al. 2011). Furthermore, these magnitude values were higher for individualism and lower for masculinity. Overall, these empirical results showed that DAs (modified Jones model) had differing effectiveness of detecting earnings management in these five society types.

Table 2. Descriptive statistics for the estimated cross section of the modified Jones model

\begin{tabular}{cc}
\hline & Dependent Variable: \\
\hline $1 / T A_{i t-1}$ & $-0.315^{* * *}$ \\
\hline$\frac{\Delta S A L E S_{i t}-\Delta A R_{i t}}{T A_{i t-1}}$ & $0.299^{* *}$ \\
$\frac{P P E_{i t}}{T A_{i t-1}}$ & $-0.224^{* *}$ \\
\hline F-value & \\
\hline$R^{2}$ & 17.832 \\
\hline Sample & 0.517 \\
\hline
\end{tabular}

Notes: $* * *$ represent significance at the $1 \%$ level, two-tailed; ** represent significance at the $5 \%$ level,

two-tailed; * represent significance at the $10 \%$ level, $A C C_{i t}$ represents the total accruals calculated as the continuing

operating net profit minus the cash flow from operations for year $t ;{ }_{i t-1}$ denotes the assets for year $t-1 ; \quad \triangle S A L E S_{i t}$ is

the change in sales for year $t ;{ }^{\Delta A R_{t}}$ is the change in account receivables for year $t$; and $P P E_{i t}$ is the gross fixed assets for year $t$. 
Table 3. Descriptive statistics for the earnings management (discretionary accruals: modified Jones model): five dimensions of culture

\begin{tabular}{lccc}
\hline power distance & 0.142 & 0.024 & 0.076 \\
\hline individualism & -0.087 & 0.026 & -0.028 \\
uncertainty avoidance & 0.028 & -0.023 & 0.001 \\
masculinity & -0.034 & -0.076 & -0.047 \\
long-term orientation & 0.128 & 0.036 & 0.072 \\
\hline
\end{tabular}

4.2 Empirical Test

We divided scaled earnings from -0.2 to +0.2 into intervals with a 0.005 width. Fig. 1 shows that managers in societies characterized by uncertainty avoidance tended to meet or exceed dividend thresholds through manipulating earnings by using a modified Jones model. This is illustrated in Panel B, which indicates a standardization difference between the negative value (-.3.71) to the left of zero and the positive value (5.47) to the right of zero, and this result is consistent with that of El- Sayed Ebaid (2012). Panel C also shows that the $\mathrm{Z}$ test resulted in a significant level and that DAs had the effect of significantly increasing the percentage of occurrences of meeting the dividends benchmark from $45.66 \%$ to $63.31 \%$, and this result is consistent with that of Gore et al. (2007). These results are consistent with H1. People in societies characterized by uncertainty-avoidance are threatened by uncertain situations. Therefore, reduced uncertainty may be engendered by earnings management, and this approach may be considered a mechanism. In other words, investors perceive that managers operate conservatively when they receive stable dividends, reducing the level of uncertainty (this is likely to be consistent with the bird-in-hand dividend theory). In societies characterized by uncertainty-avoidance, if an enterprise does not pay stable dividends, investors are reluctant to hold their stock. Hence, managers in these societies avoid engaging in earnings management through DAs (i.e., maintaining the value of dividends from the previous year) to satisfy investors.

Fig. 2 shows that managers in societies characterized by individualistic tended to meet or exceed dividend thresholds through manipulating earnings by using a modified Jones model. This is illustrated in Panel B, which indicates a standardization difference between the negative value (-.3.07) to the left of zero and the positive value (3.28) to the right of zero, and this result is consistent with that of El- Sayed Ebaid (2012). Panel C also shows that the Z test resulted in a significant level and that DAs had the effect of significantly increasing the percentage of occurrences of meeting the dividends benchmark from $60.52 \%$ to $62.65 \%$, and this result is consistent with that of Gore et al. (2007).. These results are not consistent with $\mathrm{H} 2$. In theory, highly individualistic societies are relatively transparent and competitive, and their legal and accounting rules are stringent. Therefore, people in individualistic cultures comply with the law, and the regulatory monitoring in such cultures impedes financial misreporting, causing a low adoption of earnings management. However, these results suggested that investors were still likely to obtain stable dividends. Furthermore, the percentages of observations that met and missed dividend targets before and after the management of earnings were approximately a non-difference. Therefore, we also conclude that investors are likely to prefer "gains on capital" to dividends in individualistic societies. Overall, whether dividends are an earnings threshold for managers, and whether managers may manage earnings through DAs to avoid cutting dividends, individualistic societies are difficult to analyze.

Fig. 3 shows that managers in power-distance societies tend to meet or exceed dividend thresholds through manipulating earnings by using a modified Jones model. This is illustrated in Panel B, which indicates a standardization difference between the negative value (-.4.48) to the left of zero and the positive value (6.61) to the right of zero, and this result is consistent with that of El- Sayed Ebaid (2012).Panel C also shows that the Z test resulted in a significant level and that DAs had the effect of significantly increasing the percentage of occurrences of meeting the dividends benchmark from $40.61 \%$ to $63.40 \%$, and this result is consistent with that of Gore et al. (2007). These results are consistent with H3. In high-power-distance societies, power equalization is low. Consequently, managers assuming top power positions use accounting systems as a tool to demonstrate a desired image, and they can distort accounting numbers to achieve earnings management. Most of our sample members (26 of 41) are from emerging countries in which ownership concentrations are higher than those in developed countries, showing that power inequalities are higher and individuals accept human authority and inequality. Hence, to achieve the desired image, managers avoid reducing dividends by distorting accounting numbers through earnings management.

Fig. 4 shows that managers in societies characterized by masculinity tend tended to meet or exceed dividend thresholds through manipulating earnings by using a modified Jones model. This is illustrated in Panel B, which indicates a standardization difference between the negative value (-.3.89) to the left of zero and the positive value (6.64) to the right of zero, and this result is consistent with that of El- Sayed Ebaid (2012). Panel C also shows that the Z test resulted in a significant level and that DAs had the effect of significantly increasing the percentage of occurrences of meeting the dividends benchmark from $40.11 \%$ to $61.98 \%$, and this result is consistent with that of Gore et al. (2007). These results are consistent with $\mathrm{H} 4$. The accounting systems in societies characterized by high masculinity emphasize the 
achievement of financial goals or performance. Therefore, managers tend to manage earnings more frequently to enhance their egos and achieve goals in these societies. Dividends are likely a benchmark for investors in societies characterized by high masculinity, because they signify enterprise performance. Therefore, managers provide stable dividends for investors by managing earnings above dividend thresholds to avoid negatively portraying company performance and attract investors.

Fig. 5 shows that managers tend not to meet or exceed dividend thresholds in long-term-oriented societies, although Panel B indicates a standardization difference between the negative value (-.0.32) to the left of zero and the positive value (1.97) to the right of zero. However, this absolute value is not greater than 2.33 , and this result is not consistent with that of Amar and Abaoub (2010). Furthermore, as shown in Panel C, the $Z$ test resulted in a non-significant level, and DAs were associated with a significant reduction in meeting the dividend benchmark from $37.11 \%$ to $36.69 \%$., and this result is consistent with that of Gore et al. (2007). These results are consistent with H5. because long-term-orientation societies focus on only forward-thinking values during a long-term period; short-term goals such as earnings are thus likely to be the major objective of firms operating in such societies. Hence, earnings management may not be used and dividend thresholds may also not occur in long-term-oriented societies.

Overall, numerous managers of listed firms meet or exceed dividend thresholds in four types of societies (excluding long-term-oriented societies). Furthermore, the percentage of occurrences of meeting or exceeding dividend thresholds through manipulating earnings by using a modified Jones model was higher in societies characterized by power distance $(63.40 \%)$. The change in the proportion of meeting or exceeding dividend thresholds through pre-managed earnings and manipulated earnings by using a modified Jones model was also higher in these societies. Moreover, Kahneman and Tversky (1979) presented prospect theory and reported that managers making decisions focus on the value from gains or losses with a certain reference point rather than the levels of wealth. Therefore, our study supports the notion that expected dividend levels is a measure of earnings benchmarks. Furthermore, empirical solutions may be considered to be consistent with this specific theory in four types of society. However, to avoid possible bias from extreme values, we used only samples containing data from the $5^{\text {th }}$ to the 95 th percentiles as measures for the robustness test, and the results show that most of them are consistent. To shorten the tables, we omit the solution.

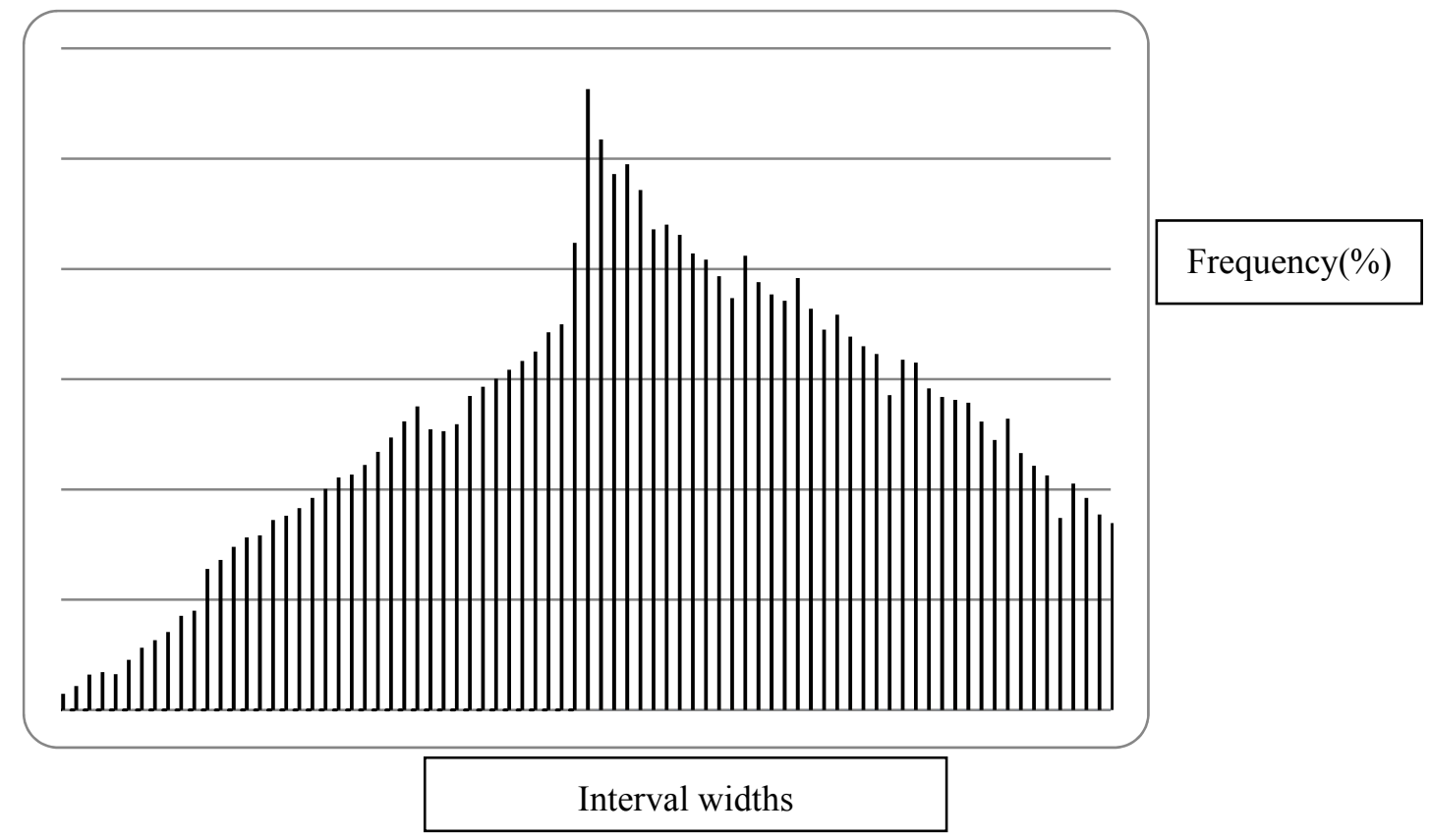

Figure 1. Distribution of earnings for the culture dimensions of Uncertainty Avoidance ( $\mathrm{N}=49847)$.

Panel A: Histogram of dividend thresholds according to managed earnings level

Panel B Distribution of managed earnings and pre-managed earnings relative to dividend targets

\begin{tabular}{cllcc}
\hline & \multicolumn{2}{c}{ earnings level } & \multicolumn{2}{c}{ Pre-managed earnings level } \\
\hline class & $-0.005<\mathbf{E}_{\mathbf{t} \leq 0}$ & $0<\mathbf{E}_{\mathbf{t} \leq 0.005}$ & $-0.005<\mathbf{E}_{\mathbf{t} \leq 0}$ & $0<\mathbf{E}_{\mathbf{t} \leq 0.005}$ \\
\hline $\mathrm{N}$ & 865 & 1221 & 1045 & 1084 \\
Std. Diff. & -3.71 & 5.47 & -0.02 & 1.99 \\
\hline
\end{tabular}


Panel C Proportions of observations achieving and missing dividend targets before and after discretionary accruals

\begin{tabular}{lllc} 
& proportion & $\mathrm{Z}$ & $\mathrm{P}$ value \\
\hline Pre-managed earnings level $>0$ & $45.66 \%$ & 121.12 & 0.000 \\
managed earnings level $>0$ & $63.31 \%$ & & \\
\hline $0<$ pre-managed earnings level $\leq 0.005$ & $2.18 \%$ & 9.02 & 0.000 \\
$0<$ managed earnings level $\leq 0.005$ & $2.45 \%$ & & 0.000 \\
\hline$-0.005<$ pre-managed earnings level $\leq 0$ & $2.10 \%$ & -13.03 & \\
$-0.005<$ managed earnings level $\leq 0$ & $1.74 \%$ & &
\end{tabular}
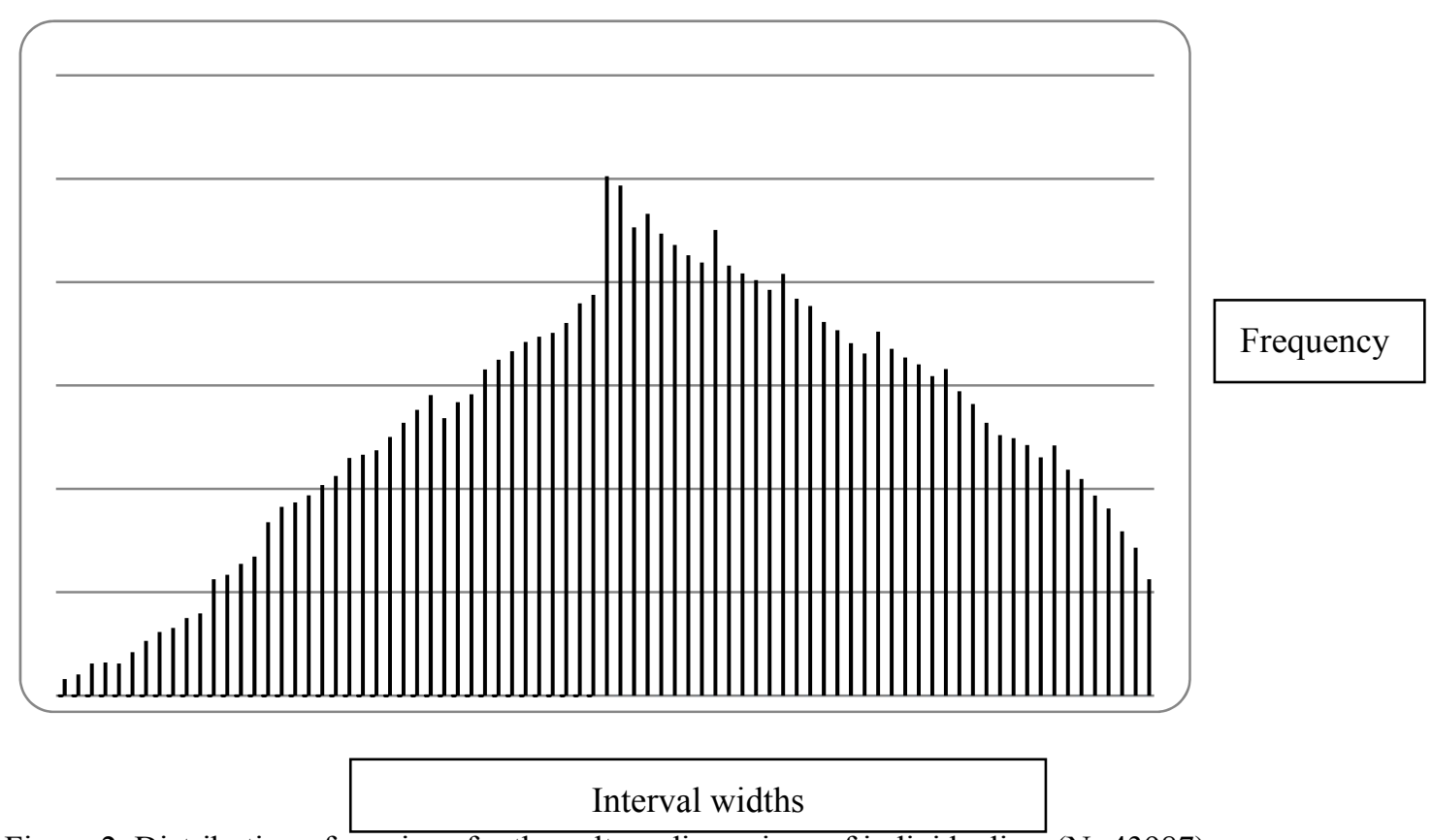

Figure 2. Distribution of earnings for the culture dimensions of individualism $(\mathrm{N}=43987)$

Panel A: Histogram of dividend thresholds according to managed earnings level

Panel B Distribution of managed earnings and pre-managed earnings relative to dividend targets

\begin{tabular}{|c|c|c|c|c|c|}
\hline \multirow[b]{2}{*}{ class } & \multicolumn{2}{|c|}{ earnings level } & \multicolumn{3}{|c|}{ pre-managed earnings level } \\
\hline & $-0.005<\mathbf{E}_{\mathbf{t}} \leq 0$ & $0<\mathrm{E}_{\mathbf{t}} \leq 0.005$ & \multicolumn{2}{|c|}{$-0.005<\mathbf{E}_{\mathbf{t} \leq 0}$} & $0<\mathbf{E}_{\mathbf{t}} \leq 0.005$ \\
\hline $\mathrm{N}$ & 790 & 1020 & \multicolumn{2}{|c|}{871} & 952 \\
\hline Std. Diff. & -3.07 & 3.28 & \multicolumn{2}{|c|}{-0.38} & 0.06 \\
\hline \multicolumn{6}{|c|}{ el C Proportions of observations achieving and missing dividends targets before and after discretionary accruals } \\
\hline & & & \multirow{2}{*}{ proportion } & Z & P value \\
\hline \multicolumn{3}{|c|}{ pre-managed earnings level $>0$} & & 4.02 & \multirow[t]{2}{*}{0.000} \\
\hline \multicolumn{3}{|c|}{ managed earnings level $>0$} & $62.65 \%$ & & \\
\hline \multicolumn{3}{|c|}{$0<$ pre-managed earnings level $\leq 0.005$} & $2.16 \%$ & 1.68 & \multirow[t]{2}{*}{0.093} \\
\hline \multicolumn{3}{|c|}{$0<$ managed earnings level $\leq 0.005$} & $2.32 \%$ & & \\
\hline \multirow{2}{*}{\multicolumn{3}{|c|}{$\begin{array}{l}-0.005<\text { pre-managed earnings level } \leq 0 \\
-0.005<\text { managed earnings level } \leq 0\end{array}$}} & $1,98 \%$ & -1.99 & \multirow[t]{2}{*}{0.046} \\
\hline & & & $1.80 \%$ & & \\
\hline
\end{tabular}




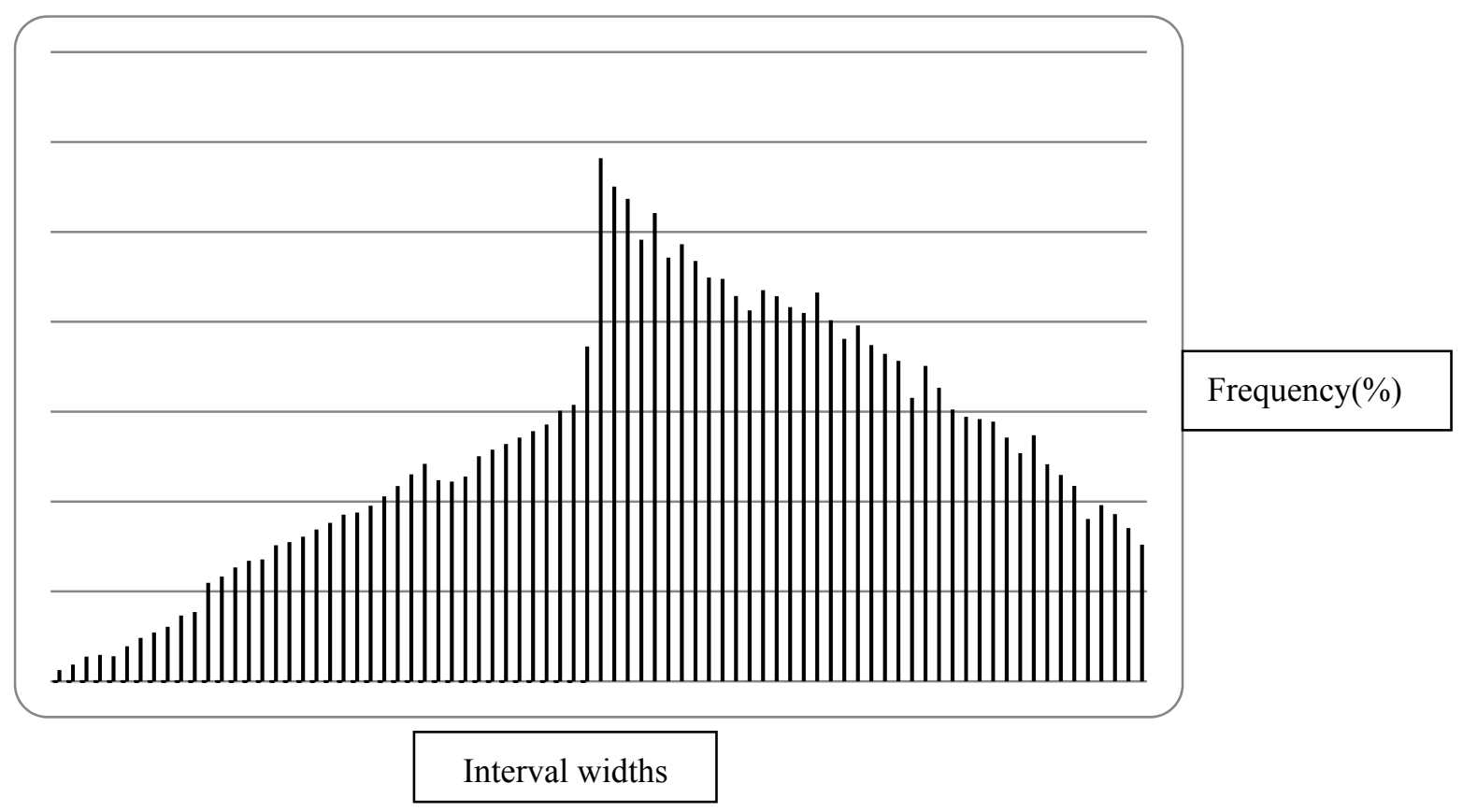

Figure 3. Distribution of earnings for the culture dimensions of power-distance $(\mathrm{N}=61965)$

Panel A: Histogram of dividends thresholds according to managed earnings level

Panel B Distribution of managed earnings and pre-managed earnings relative to dividend targets

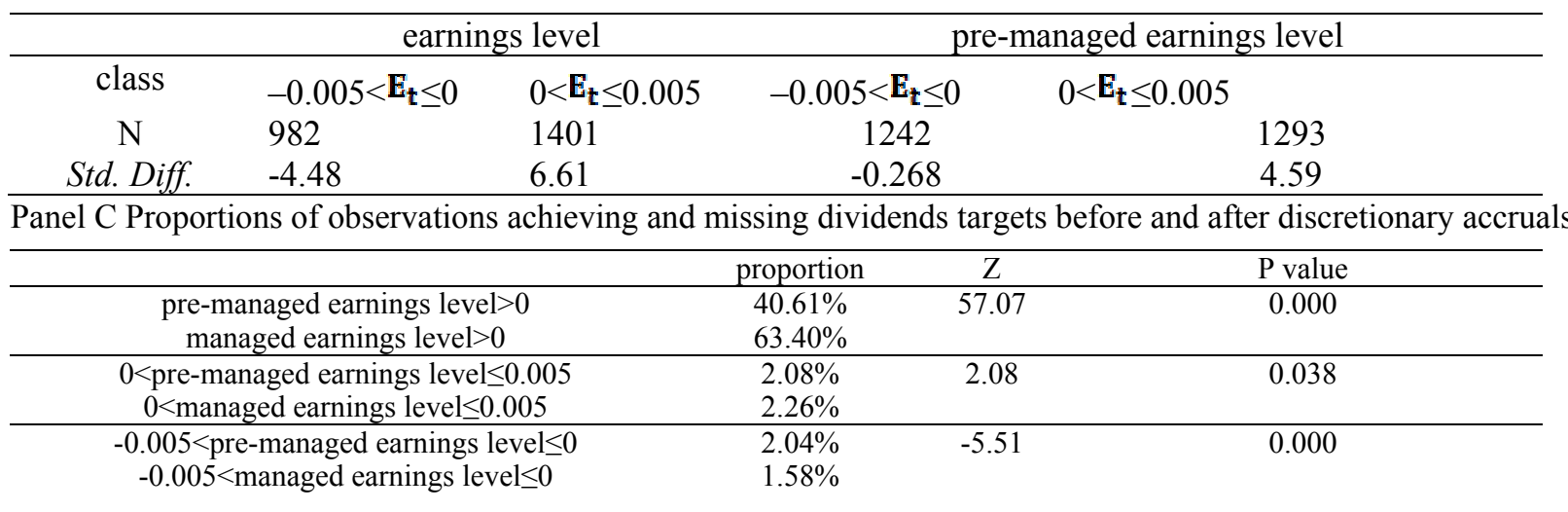

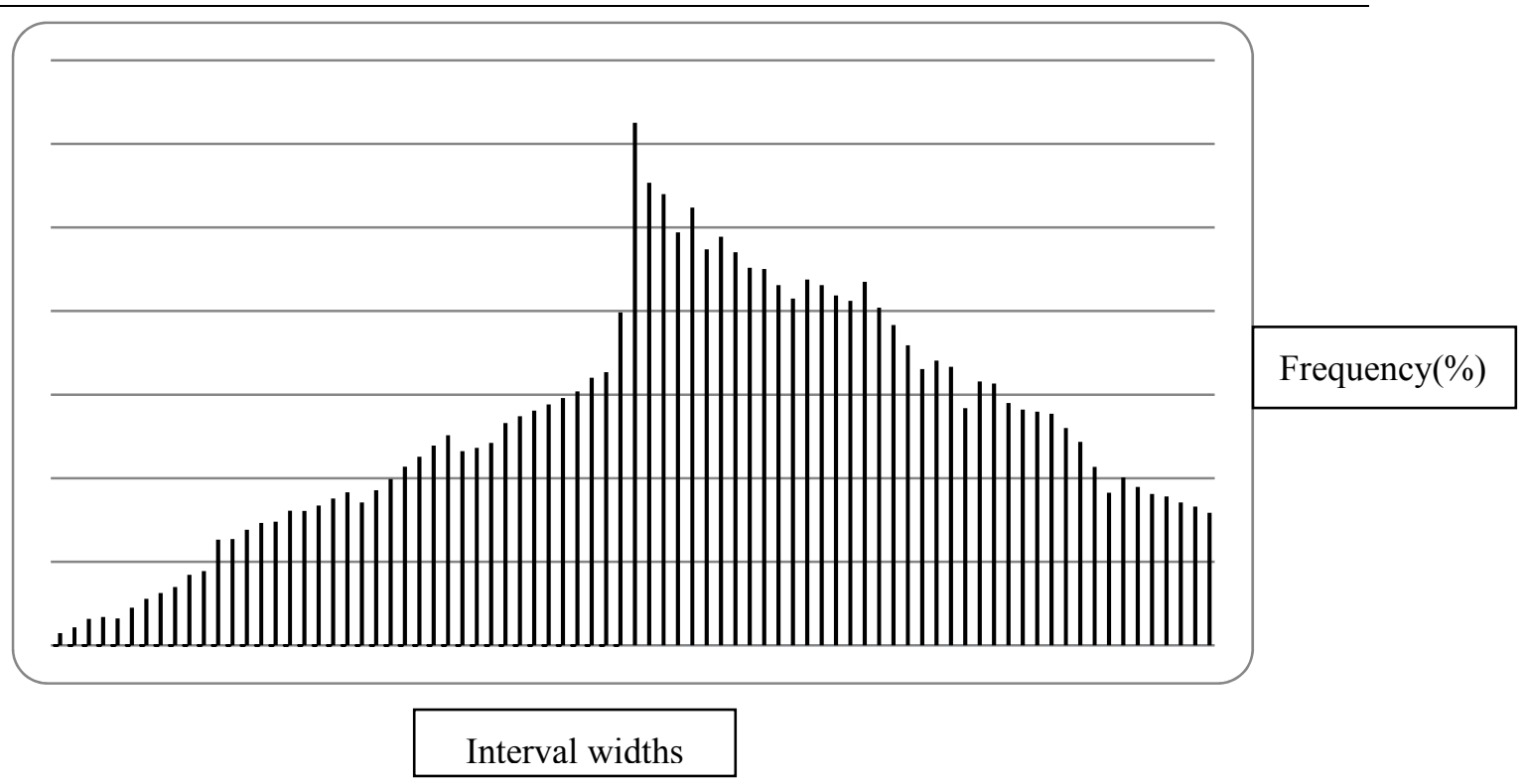

Figure 4. Distribution of earnings for the culture dimensions of masculinity $(\mathrm{N}=61996)$ 
Panel A: Histogram of dividends thresholds according to managed earnings level

Panel B Distribution of managed earnings and pre-managed earnings relative to dividend targets

\begin{tabular}{cllcr}
\hline & \multicolumn{2}{c}{ earnings level } & \multicolumn{2}{c}{ pre-managed earnings level } \\
\hline class & $-0.005<\mathbf{E}_{\mathbf{t}} \leq 0$ & $0<\mathbf{E}_{\mathbf{t}} \leq 0.005$ & $-0.005<\mathbf{E}_{\mathbf{t}} \leq 0$ & $0<\mathbf{E}_{\mathbf{t} \leq 0.005}$ \\
$\mathrm{~N}$ & 1035 & 1489 & 1394 & 1270 \\
Std. Diff. & -3.89 & 6.64 & 3.34 & -0.91 \\
\hline
\end{tabular}

Panel C Proportions of observations achieving and missing dividends targets before and after discretionary accruals

\begin{tabular}{llll}
\hline & proportion & $\mathrm{Z}$ & $\mathrm{P}$ value \\
\hline pre-managed earnings level $>0$ & $40.11 \%$ & 55.19 & 0.00 \\
managed earnings level $>0$ & $61.98 \%$ & & \\
\hline $0<$ pre-managed earnings level $\leq 0.005$ & $2.05 \%$ & 6.044 & 0.00 \\
$0<$ managed earnings level $\leq 0.005$ & $2.40 \%$ & & \\
\hline$-0.005<$ pre-managed earnings level $\leq 0$ & $2.24 \%$ & -10.56 & 0.00 \\
$-0.005<$ managed earnings level $\leq 0$ & $1.67 \%$ & & \\
\hline
\end{tabular}

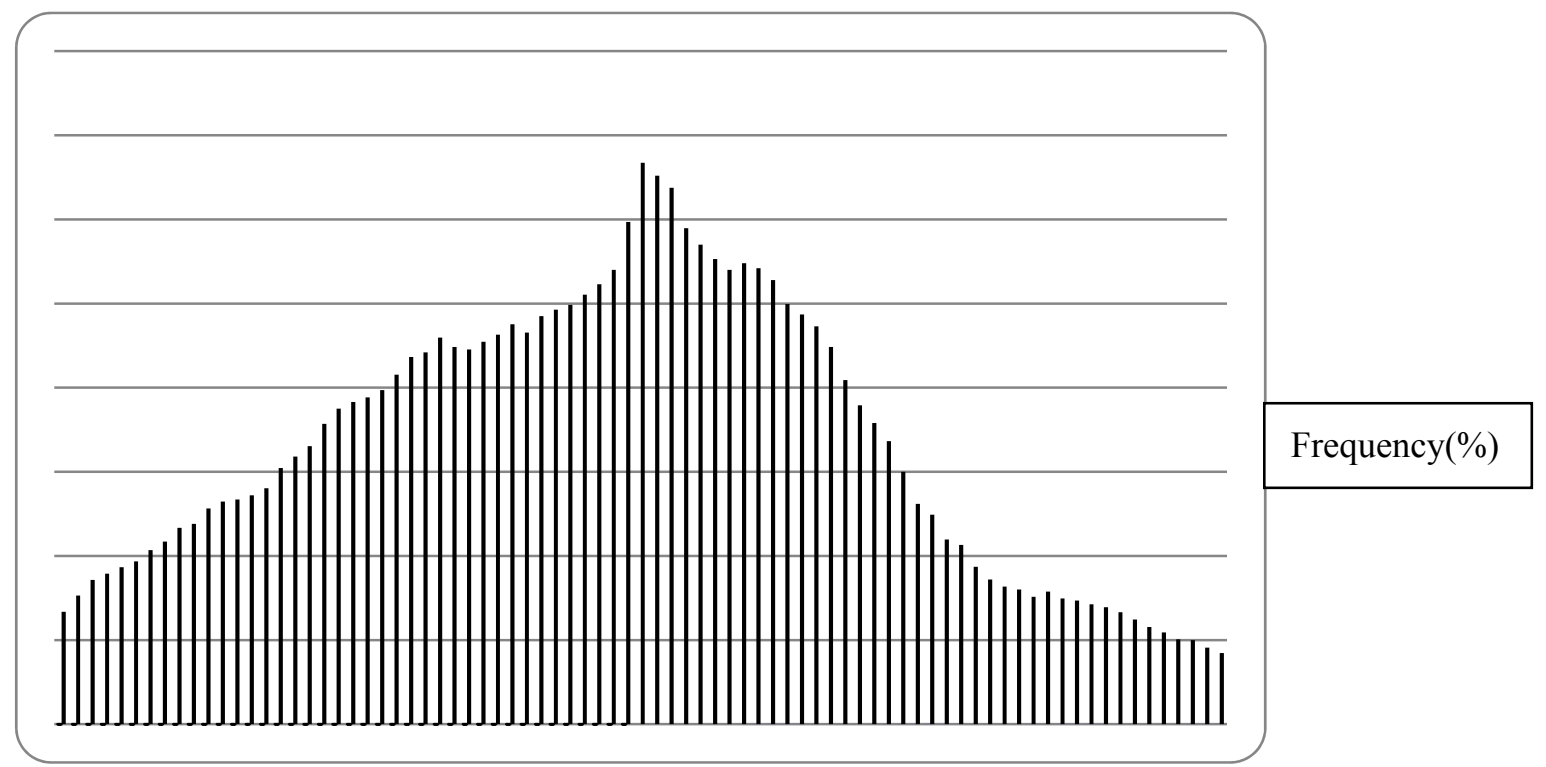

Interval widths

Figure 5. Distribution of earnings for the culture dimensions of long-term-oriented ( $\mathrm{N}=54298)$

Panel A: Histogram of dividends thresholds according to managed earnings level

Panel B Distribution of managed earnings and pre-managed earnings relative to dividend targets

\begin{tabular}{cllcc}
\hline & \multicolumn{2}{c}{ earnings level } & \multicolumn{2}{c}{ pre-managed earnings level } \\
\hline class & $-0.005<\mathbf{E}_{\mathbf{t}} \leq 0$ & $0<\mathbf{E}_{\mathbf{t}} \leq 0.005$ & $-0.005<\mathbf{E}_{\mathbf{t}} \leq 0$ & $0<\mathbf{E}_{\mathbf{t}} \leq 0.005$ \\
$\mathrm{~N}$ & 1194 & 1335 & 1078 & 1147 \\
Std. Diff. & -0.321 & 1.971 & -0.062 & 1.754 \\
\hline
\end{tabular}

Panel C Proportions of observations achieving and missing dividends targets before and after discretionary accruals

\begin{tabular}{llll}
\hline & proportion & $Z$ & P value \\
\hline pre-managed earnings level $>0$ & $37.11 \%$ & -1.11 & 0.267 \\
managed earnings level $>0$ & $36.69 \%$ & & \\
\hline $0<$ pre-managed earnings level $\leq 0.005$ & $1.72 \%$ & 5.03 & 0.000 \\
$0<$ managed earnings level $\leq 0.005$ & $2.14 \%$ & & \\
\hline$-0.005<$ pre-managed earnings level $\leq 0$ & $1.85 \%$ & 4.01 & 0.000 \\
$-0.005<$ managed earnings level $\leq 0$ & $2.20 \%$ & & \\
\hline
\end{tabular}




\section{Conclusion}

Accounting rules and practices are influenced by culture. Dividends influence corporate decisions, and expected dividends represent an earnings threshold. We analyzed the manipulation of income toward a dividend threshold in various countries and determined whether those perceptions are influenced by cultural factors. Data from 2004 to 2014 were collected from the COMPUSTAT database. The empirical results show that managers of listed firms in societies characterized by uncertainty avoidance, individualism, power-distance and masculinity tend to meet or exceed dividend thresholds, whereas managers in long term orientation societies do not.

These findings emphasize the strong and direct effect of cultural values on meeting or exceeding dividend thresholds through earnings management over multiple years. In addition, our empirical results suggest that investors evaluate firm performance (i.e., earnings) before dividends are paid, which should be considered by financial market participants and regulators when assessing financial statements and the reliability of financial reporting among multiple countries.

However, this study has limitations. Dividends are almost always issued as cash dividends. However repurchases and stock dividends may also be issued. Therefore, net shareholder cash flow may not represent the overall dividend threshold, and researchers could stress the importance of firms' pay-out components. In addition, future studies could investigate the effects of culture on achieving the earning expectations of analysts. We used a modified Jones model to measure earnings management. Therefore, tradeoff tools (i.e., real activities or other DA models) should be used to examine earnings management among managers to ensure the robustness of our results. Finally, because numerous countries have adopted international financial accounting standards as their accepted GAAP, future studies could use this information to explain systematic differences in earnings management that have resulted from cultural differences.

\section{References}

Amar, A. B., \& Abaoub, E. (2010). Earnings management thresholds: The case in Tunisia. Asian Academy of Management Journal of Accounting and Finance, 6(2), 35-56.

Ashraf, B. N. (2014). National Culture and Dividend Policy: International Evidence from Banking. Journal of Behavioral and Experimental Finance, 3, 22-40. https://doi.org/10.1016/j.jbef.2014.07.002

Athanasakou, V., Strong, N., \& Walker, M. (2011). The market reward for achieving analyst earnings expectations: Does managing expectations or earnings matter. Journal of Business Finance and Accounting, 38(1) \& (2), 58-94. https://doi.org/10.1111/j.1468-5957.2010.02219.x

Bae, S. C., Chang, K., \& Kang, E.(2012). Culture, corporate governance, and dividend policy: international evidence. Journal of Financial Research, 35, 289-316. https://doi.org/10.1111/j.1475-6803.2012.01318.x

Bennet, B., \& Bradbury, M. E. (2007). Earnings thresholds related to dividend cover. Journal of International Accounting and Research, 6(1), 1-17. https://doi.org/10.2308/jiar.2007.6.1.1

Burgstahler, D., \& Dichev, I. (1997). Earnings management to avoid earnings decreases and losses. Journal of Accounting and Economics, 24, 99-126. https://doi.org/10.1016/S0165-4101(97)00017-7

Chen, H., Chen, J. Z., Lobo, G. J., \& Wang, Y. (2011). Effects of audit quality on earnings management and cost of equity capital: evidence from China. Contemporary Accounting Research, 28(3), 892-925. https://doi.org/10.1111/j.1911-3846.2011.01088.x

Daniel, N., Denis D., \& Naveen, L. (2008). 'Do firms manage earnings to meet dividend thresholds? Journal of Accounting and Economics, 45, 2-26. https://doi.org/10.1016/j.jacceco.2007.11.002

Deangelo, H., \& Deangelo, L. (2006a). The irrelevance of the MM dividend irrelevance theorem. Journal of Financial Economics, 79, 293-315. https://doi.org/10.1016/j.jfineco.2005.03.003

Dechow, P., Ge, W., \& Schrand, C. (2010b). Understanding earnings quality: A review of the proxies, their determinants, and their consequences. Journal of Accounting and Economics, 50,344-401. https://doi.org/10.1016/j.jacceco.2010.09.001

Dechow, P., Saloan, R., \& Sweeney, A. (1995). Detecting earning management. The Accounting Review, 70,193-225.

Degeorge, F., Ding, Y., Jean, T., \& Stolowy, H. (2013). Analyst coverage, earnings management and financial development: An international study. Journal of Accounting and Public Policy, 32, 1-25.

https://doi.org/10.1016/j.jaccpubpol.2012.10.003

Desender, K. A., Castro, C. E., \& Escamilla De Leon, S. A. (2011). Earnings management and cultural values. American Journal of Economics and Sociology, 70(3), 639-670. https://doi.org/10.1111/j.1536-7150.2011.00786.x

Doupnik, T. S. (2008). Influence of culture on earnings management: A note. Abacus, 44(3), 317-340. https://doi.org/10.1111/j.1467-6281.2008.00265.x 
Doupnik, T., \& Tsakumis, G. (2004). A critical review of tests of Gray's theory of cultural relevance and suggestions for future research. Journal of Accounting Literature, 23, 1-48.

El-Sayed Ebaid, I.(2012). Earnings management to meet or beat earnings thresholds evidence from the emerging capital market of Egypt. African Journal of Economic and Management Studies, 3(2), 240-257. https://doi.org/10.1108/20400701211265027

Farrell, K., Unlu, E., \& Yu, J. (2014). Stock repurchases as an earnings management mechanism: The impact of financing constraints. Journal of Corporate Finance, 25, 1-15. https://doi.org/10.1016/j.jcorpfin.2013.10.004

Fidrmuc, J. P., \& Jacob, M. (2010). Culture, agency costs, and dividends. Journal of Comparative Economics, 38(3), 321-339. https://doi.org/10.1016/j.jce.2010.04.002

Francoeur, C., Amar, W. B., \& Rakoto, P. (2012). Ownership structure, earnings management and acquiring firm post-merger market performance Evidence from Canada. International Journal of Managerial Finance, 8(2), 100-119. https://doi.org/10.1108/17439131211216594

Gore, P., Pope, .F., \& Singh, A. K. (2007). Earnings management and the distribution of earnings relative to targets: UK evidence. Accounting and Business Research, 37(2), 123-150. https://doi.org/10.1080/00014788.2007.9730065

Guan, L., \& Pourjalali, H. (2010). Effect of cultural environmental and accounting regulation on earnings management: A multiple year-country analysis. Asia-Pacific Journal of Accounting and Economics, 17, 99-127. https://doi.org/10.1080/16081625.2010.9720856

Han, S., Kang, T., Salter, S., \& Yoo, Y. K. (2010). A cross-country study on the effects of national culture on earnings management. Journal of International Business Studies, 41, 123-141. https://doi.org/10.1057/jibs.2008.78

Healy, P. M., \& Wahlen, J. M. (1999). A review of the earnings management literature and its implications for standard setting. Accounting Horizons, 13(4), 365-383. https://doi.org/10.2308/acch.1999.13.4.365

Heidarpoor, F., Rafiee, S. Z., \& Rafiee, S. Z. (2014). Drivers of earnings management: the profit and loss before earning management. International Journal of Accounting and Financial Reporting, 4(2), 23-49. https://doi.org/10.5296/ijafr.v4i2.5674

Hofstede G., Hofstede G. J., Minkov, M. (2010). Cultures and Organizations: Software of the Mind. Revised and Expanded 3rd Edition. New York: McGraw-Hill USA, 2010

Hofstede, G. (1980). Culture's consequences: International differences in work-related values. Beverly Hills: Sage Publications.

Hofstede, G. (1991).Cultures and Organizations: Software of the Mind. New York

Hofstede, G. (2001). Culture's Consequences: Comparing Values, Behaviors, Institutions, and Organizations across Nations. Thousand Oaks, CA: Sage Publications.

Hofstede, G., \& Hofstede, G. J. (2005). Cultures and Organizations: Software of the Mind. New York: McGraw-Hill.

Kahneman, D., \& Tversky, A. (1979). Prospect theory: an analysis of decision under risk,' Econometrica, 47, 263-291. https://doi.org/10.2307/1914185

Kanagaretnam, K., Lim, C. Y., \& Lobo, G. J. (2011). Effects of national culture on earnings quality of banks. Journal of International Business Studies, 42, 853-874. https://doi.org/10.1057/jibs.2011.26

Karampinis, N. I., \& Hevas, D. L. (2013). Effects of IFRS adoption on tax-induced incentives for financial earnings management: Evidence from Greece. The International Journal of Accounting, 48, 218-247. https://doi.org/10.1016/j.intacc.2013.04.003

Khambata, D., \& Liu, W. W. (2005). Cultural dimensions, risk aversion and corporate dividend policy. Journal of Asia-Pacific Business, 6, 31-43. https://doi.org/10.1300/J098v06n04_03

Kinnunen, J., \& Koskela, M. (2003). Who is miss world in cosmetic earnings management? A cross-national comparison of small upward rounding of net income numbers among eighteen countries. Journal of International Accounting Research, 2, 39-68. https://doi.org/10.2308/jiar.2003.2.1.39

Koren, J., \& Valentincic. A. (2013). Shareholders's pay-out-related thresholds and earnings management. Economic and Business Review, 15(2), 151-173.

Lintner, J. (1956). Distribution of incomes of corporations among dividends, retained earnings, and taxes. American Economic Review, 46, 97-113.

Liu, N., \& Espahbodi, R. (2014). Does dividend policy drive earnings smoothing. Accounting Horizons, 28(3), 501-528. https://doi.org/10.2308/acch-50764 
Nabar, S., \& Boonlert-U-Thai, K. (2007). Earnings management, investor protection, and national culture. Journal of international accounting research, 6(2), 35-54. https://doi.org/10.2308/jiar.2007.6.2.35

Othman, H. B., \& Zeghal, D. (2006). A study of earnings-management motives in the Anglo-American and Euro-Continental accounting models: The Canadian and French cases. The International Journal of Accounting, 41, 406-435. https://doi.org/10.1016/j.intacc.2006.09.004

Peterson, R., \& Whitworth, J. (2013). A reexamination of the dividend threshold. Academy of Business Research Journal, 3, 44-56.

Shao, L., Kwok, C. C., \& Guedhami, O. (2009). National culture and dividend policy. Journal of International Business Studies,41, 1391-1414. https://doi.org/10.1057/jibs.2009.74

Sun, L., \& Rath, S. (2012). Pre managed earnings benchmarks and earnings management of Australian firms. Australasian Accounting, Business and Finance Journal, 6(1), 29-56.

Waterman, A. S. (1984). The psychology of individualism. New York: Praeger

Zhang, X., \& He, Y. (2013). R\&D-based earnings management, accounting performance and market return: Evidence from national-recognized enterprise technology centers in China. Chinese Management Studies, 7(4), 572-585. https://doi.org/10.1108/CMS-09-2013-0176

Zhang, X., Liang, X., \& Sun, H. Y. (2013). Individualism-collectivism, private benefits of control, and earnings management: A cross-culture comparison. Journal of Business Ethics, 114, 655-664. https://doi.org/10.1007/s10551-013-1711-5

Zheng, C., \& Ashraf, B. N. (2014). National culture and dividend policy: international evidence from banking. Journal of Behavioral and Experimental Finance, 3, 22-40. https://doi.org/10.1016/j.jbef.2014.07.002

\section{Copyrights}

Copyright for this article is retained by the author(s), with first publication rights granted to the journal.

This is an open-access article distributed under the terms and conditions of the Creative Commons Attribution license which permits unrestricted use, distribution, and reproduction in any medium, provided the original work is properly cited. 